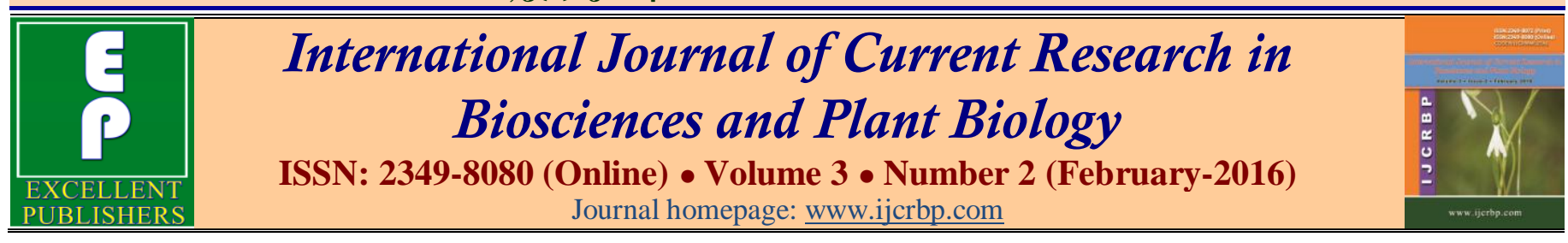

Original Research Article

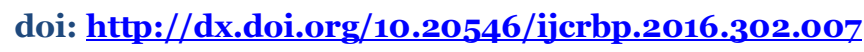

\title{
Ethnobotanical Study of Some Threatened Plants in District Baramulla, Kashmir, Jammu and Kashmir, India
}

\author{
Zishan Ahmad Wani*, Narendra Kumar and Akash \\ Department of Botany, Uttaranchal College of Science and Technology, Dehradun, Uttarakhand, India \\ *Corresponding author.
}

\begin{abstract}
In Kashmir valley, the plants have been used for treating various diseases from ancient times. About 700 plant species are being used as medicine in one or other form in Kashmir valley. This knowledge regarding the use of medicinal plants was transmitted from generation to generation orally. This traditional knowledge regarding the use of medicinal plants is draining off due to modernization. Also a number of plant species have been rendered threatened due to various anthropogenic as well as natural threats like overgrazing, deforestation, building of roads, overexploitation, soil erosion, huge tourism influx etc. A survey was conducted in the Baramulla District of Kashmir to document the ethnobotany of the rare, vulnerable and endangered plants of the area. During the study 27 plants were documented along with their medicinal uses and status of conservation.
\end{abstract}

\section{Article Info}

Accepted: 17 January 2016

Available Online: 06 February 2016

Ke ywords

Allopathic medicines

Endangered plants

Traditional

Tribal people

Vulnerable

\section{Introduction}

Ethnobotany is the study of how people of a particular culture and region make use of indigenous plants. Ethnobotany is the scientific study of the relationships that exist between people and the plants. Ethnobotany aims to document the valuable knowledge of the tribal regarding the use of plants. The tribal people use the plants in their unique ways for various purposes mostly for the treatment of various diseases (Kumar et al., 2015). Ethnobotanists explore how plants are used for such things as food, shelter, medicine, clothing, hunting and religious ceremonies. Ethnobotany has its roots in botany, the study of plants. The investigation of plants and their uses is one of the most primarily human concern and have been practiced by all cultures for tens, if not hundreds or thousands of years though it was not called ethno botany then. Ethnobotany is the scientific study of plant lore and agricultural customs of the people. Given their extensive range of knowledge, indigenous people remain the ultimate resource for the purpose of application, particularly in modern medicine. Ethno medicinal investigations have led to the development of important drugs such as reserpine (a treatment for hypertension), podophyllotaxin (the base of an important anti-cancer drug) and vinblastin-a (used in the treatment of certain cancers) (Idu, 2009).

Demands for medicinal plants are increasing in both developing and developed countries. As per WHO estimate, about $80 \%$ of the population in developing countries depends directly on plants for medicine (Itoo, 2011). Ethnobotany, in its totality, is virtually an old field with new dimensions of research, and if this field is investigated thoroughly and systematically, it will yield results of great value missing the ethnologists, archaeologists, botanists and linguists and ultimately to pharmacologists and phytochemists. It will appear to be a bridge between botany and medicinal plants (Mahbubur Rehman, 2013). Ethnobotanical information on medicinal plants and their use by indigenous cultures is useful not only in conservation of traditional cultures, but also for community health care and drug development (Farooq et al., 2011). 
Historically, the knowledge of the medicinal plants was restricted to few specialized herbal healers in rural communities, thus much of their use was seen as being primarily of local interest. For the past 2 decades medicinal plants has been increasingly recognized for their role in improving the economic status of rural people, who sell these plants in markets worldwide. Threatened medicinal plants have become the focus of world attention because they represent an extending flora which need protection and conservation and because of their role as an essential commodity for health care. The use of plants in modern medicine has considerably increased, on the other hand, traditional knowledge is gradually decreasing due to rapid urbanization and dependence of man on modern health care systems, but this folk system still prevails in the rural communities (Ahmad et al., 2014).

Medicinal plants are still widely used for health care by tribal. As the new generation is diverted towards the allopathic medicines, ethnobotanical knowledge of important medicinal plants remained restricted to the old people only (Amjad et al., 2014). The United Nations through WHO programmes sought to promote and develop traditional medicine in the health care systems to integrate traditional medicine and modern medicine and to promote manpower development and research in traditional medicine (Adachukwu and Yusuf, 2014). According to data released by the WHO, ethnomedicine has maintained its popularity in all regions of the developing world and its use is rapidly expanding in the industrialized countries. For instance in China, traditional herbal preparations account for $30-50 \%$ of the total medicinal consumption. In Ghana, Nigeria and Zambia, the first line of the treatment for $60 \%$ of the children with malaria is the use of herbal medicine (Bhat et al., 2012).

The use of medicinal plants for the treatment of diseases and infection is as old as mankind. Therefore many indigenous plants are used in traditional medicine to cure diseases and infections. These ancient and indigenous medicinal practices were discovered but then could not be proven by scientific theories, but the results have been beneficial and efficient to the people (Adachukwu and Yusuf, 2014). Now due to the zeal and zest of the workers the present demand for the ethno medicinal plants is approximately $\$ 14$ billion per year (Sharma, 2010).

India is one of the 17 mega biodiversity countries in the world. It has 45000 plant species, out of which 1500020000 plants have medicinal values (Arti et al., 2014).
India has 10 of the world's biodiversity wealth which is distributed across 16 agro climatic zones (Raut et al., 2010). Plants have been used by tribal and local people for cure of various diseases. As most of the diseases of modern society are style diseases and the use of medicinal plants can overcome such problems. Moreover several difficult diseases have problems related with vitality, diabetes; memory loss could be cured effectively by the use of herbal medicine which generally is not possible by the allopathic medicines (Agarwal et al., 2013). Importance of medicinal plants in traditional health care practices which provide clues to new areas of research and in biodiversity conservation is now well known. However, information on the uses of plants for medicine is lacking from many hilly and tribal areas of Kashmir Himalayas (Jeelani et al., 2013). The use of plants for medicinal purposes and human sustenance has been in practice in India since Vedic times. The earliest mention of the medicinal use of the plants is found in Rig-Veda (1500-400 B.C) and Atharveda (1500 BC). In India, about 17000 plant species out of which 7500 are known for medicinal uses. In India, Ammal initiated the work on ethno botany while working in BSI (Mahesh Kumar et al., 2009).

India and China are two of the largest countries in Asia which have the richest arrays of registered and relatively well known medicinal plants. India has a rich wealth of medicinal plants and is unique in that these plants are used by all sections of people either directly as folk remedies or in different indigenous systems of medicine or indirectly in the pharmaceutical preparations of modern medicine. The knowledge of medicinal plants has been accumulated in the course of many centuries based on different Indian systems of medicine such as Ayurveda, Unani and Siddha (Lone et al., 2013). WHO has listed over 21000 plant species used around the world for medicinal purposes. In India, about 2500 plant species are being used in indigenous systems of medicine. The Red Data Book lists 427 Indian medicinal plant entries on endangered species, of which 28 are considered extinct, 124 endangered, 81 rare and 34 insufficiently known (Akshay et al., 2014). In India a large population known as tribal lives in forests. Tribal people are ecosystem people who live in harmony with nature and maintain close link between man and environment (Das et al., 2009).

Kashmir Himalaya, perched at the North- Western tip of the Himalayan Biodiversity Hotspot, supports a rich and spectacular biodiversity of great scientific curiosity and promising economic benefits chiefly owing to its 
topographical variations spanning from valley floor through terraced lands and dense forests up to snow capped alpine peaks (Khuroo et al., 2007). In western Himalayas, indigenous species are traditionally used by the locals for problems including acne (16\%), hair growth (11\%), bad teeth (12\%), facial spots (9\%), fairness $(18 \%)$, wrinkles $(8 \%)$ and eyes and lip care $(9 \%)$ (Shaheen et al., 2014). Singh (2013), conducted ethno botanical surveys in the entire Lahaul- Spiti region of Indian Western Himalayas to highlight the traditional uses of medicinal plants by the native people. The results revealed that tribal communities of both Lahaul - Spiti valley have a great respect for and faith in Amchi system of medicine practiced in the entire region. Since ages through trial and error, people in the Himalayan region have learned and practiced the medicinal usage of plants growing in their close vicinity for treating various ailments.

The priced ancient wisdom usually been disseminated verbally requires to be documented urgently. Kashmir has been occasionally been explored by a number of botanists prominent among them are Victor Jacquement* (18011832), Baron Von Huegal and Godfrey Thomas* (18361838), Royals Collectors* (1833-1839), W. Moorcroft and G. Trebeck* (1841), J. E. Winterbottom* (1846), Thomas* (1847), Schalgintweit brothers* (1854-1857), G. Handerson and A. O. Hume* (1873), William Hey* (1862), J. L. Stewart* (1868) and J. F .Duthie* (18921893). The early $20^{\text {th }}$ century saw the work of A. Meebold* (1905), F. Hallbarg* (1921). B. O. Coventry* (1925), E. Blatter* (1927-28), Walter Koelz* (1930), S. k. Mukherji* (1940) and W. J .Lambert* (1933) who published their work in the form of manuals and floras. Their work was followed by that of F. W. Pennel* (1943) and F. Ludlow* (1951). In recent years R. R. Stewart and T.A Rao from BSI extensively explored many places with a view to prepare comprehensive flora of the region. While R. N. Chopra and his co-workers published a series of papers on the medicinal and aromatic plants of the area (Dutt et al., 1963). During the last half century only few studies have been carried out to document the ethno medicinal plant species growing in the region particularly in the remote and difficult terrains (Malik, 2010).

The valley of Kashmir is known for its beauty all over the world is also rich in herbal and floral wealth. The interest in knowing and admiring the plants in Kashmir has existed since times immemorial. In Kalhana's Rajtarangini (1149-50 A.D), we find mention of preservation of plants and plant products for medicinal purposes. Sir Walter Lawrence in his 'Valley of
Kashmir' has observed that 'Kashmiris turn nearly every plant to some use and attribute medicinal properties to every growing thing'. The present study has been undertaken to study the ethnomedicinal plants in Baramulla district of Kashmir with reference to threatened species.

\section{Materials and methods}

\section{Study site}

Baramulla district is one of the 22 districts in the Indian state of Jammu and Kashmir. Baramulla city is the administrative head quarters of this district. The district covered an area of $4190 \mathrm{~km}^{2}$ in 2001 but it was reduced to $353 \mathrm{~km}^{2}$ at the time of 2011 census.

$\begin{array}{ll}\text { Country } & : \text { India } \\ \text { State } & : \text { Jammu and Kashmir } \\ \text { Coordinates } & : 34.1980^{\circ} \mathrm{N} 74.3636^{\circ} \mathrm{E} \\ \text { Total area } & : 3,353 \mathrm{~km}^{2} \\ \text { Population } & : 1,015,503 \\ \text { Density } & : 305 / \mathrm{km}^{2}\end{array}$

Administration: Baramulla district comprises eight tehsils: Pattan, Uri, Kreeri, Boniyar, Tangmarg, Sopore, Rafiabad and Baramulla. Baramulla district has seven constituencies: Uri, Rafiabad, Sopore Sangrama, Baramulla and Pattan.

Demographics: According to the 2011 census Baramulla district has a population of $1,015,503$. Of the total population 542,171 were males and 473,332 were females. The district has the density of $305 / \mathrm{km}^{2}$. Its population growth rate over the decade 2001-2011 was $20.34 \%$. Baramulla has a literacy rate of $66.93 \%$.

Geography: The district is spread from Srinagar district and Ganderbal district in the east to the line of control in the west and from Kupwara district in the north and Bandipora district in the northwest to Poonch district in the south and Budgam district in the southwest.

Tourism: Baramulla district is a paradise for tourists. Gulmarg village is a hill station in Baramulla district and famous for its skiing slopes at $2,730 \mathrm{~m}$. It has a cable car reaching the start of the skiing slope. Gulmarg can access from Srinagar, $50 \mathrm{~km}$ to the east. Some other tourism attractions in the Baramulla district are Tangmarg, Wular Lake, Manasbal Lake, Minimarg, Vijimarg and Mahalishamarg. 
Languages: The commonly used language is Kashmiri, followed by Gujari, Hindi and Punjabi.

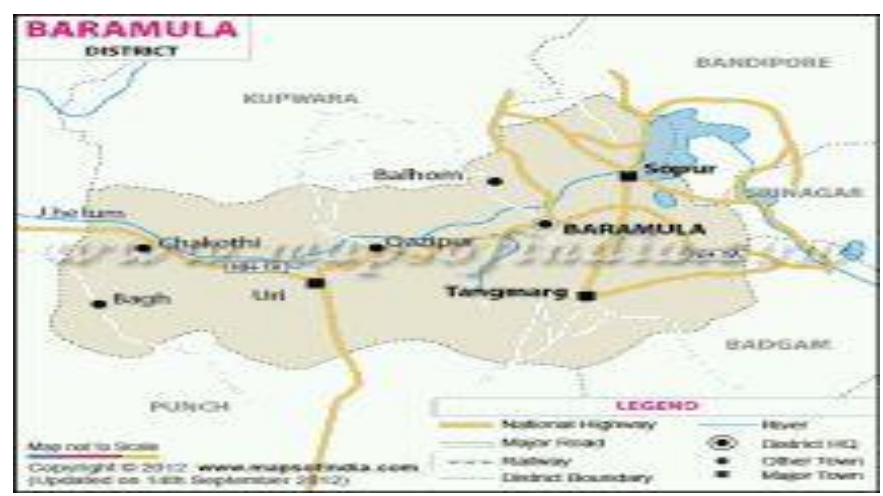

Fig. 1: The present study area, Baramulla district.

\section{Methodology}

During this investigation field trips were carried out to the area of study during April-June in 2015. Appropriate methodology was used to obtain the information about the medicinal uses of different plants from the local population. The information was collected from the people by using questionnaire. The local herbal healers (hakeems) were mostly consulted during the study. The information given by these persons was verified by confirming it from at least 5 other persons. Then we searched for these plants and the snaps of the plants were taken in their natural habitat with a digital camera. Some of the photographs and data have been taken from internet and the library of Uttaranchal College of Science and Technology, Dehradun.

\section{Results and discussion}

During the ethnobotanical exploration, 27 threatened plants were documented along with their ethnobotanical uses (Table 1). Out of the 27 plants studied 8 are rare, 7 are vulnerable, 7 endangered and 5 critically endangered (Fig. 2). These plants belong to 22 families. Most of these are herbs. These plants are being used from ancient times for curing many diseases and ailments like cough, fever, rheumatism, constipation, boils, etc. (Table 1).

Kashmir Himalaya harbours diverse habitats which supports a rich floristic wealth that has been used as a source base by its people since times immemorial. Kashmir valley provides home to a large number of plant species. The hospitable approach is not only restricted to native species but to exotic as well (Aslam et al., 2010). Indeed Kashmir is known for its economically valued plants and their products such as medicine, fodder, fibre etc. Owing to the rich and unique floristic diversity a good proportion of plants are used as medicine in one form or other. The ethnic use of some of these herbs in medicine through folklore as well as in the document form dates back to 3000-1000 B. C and was in all probability the only means of curing and protecting the human population from various diseases. The shrinking population of some plants on account of very high demand for medicinal purposes is a matter of great concern as these plants are the backbone of our traditional medicinal system with a large population still depending on traditional medicine. Therefore, the need to conserve these plants is of utmost importance because if necessary conservation measures are not taken at the earliest, the day will not be far away when these God gifted resources will completely deplete from their natural habitats (Lone et al., 2014).

The Kashmir Himalaya has rich diversity and many medicinal plants grown in this area. But about $70 \%$ of the identified medicinal plants are exposed to destructive harvesting (Khan et al., 2004). In J \& K, India, law enforcement has banned the collection of the medicinal plants from the wild except for the Gaddi, Gujjars and Bakarwal tribes who are permitted to collect the species for their personal uses only. As a consequence, knowledge of medicinal plants lies with tribes only (Dutt et al., 2015). In recent times serious threats of biopiracy and intellectual property rights with huge economy at stake, have necessitated the early bio-prospecting of the potential medicinal plants used in the folklore. In this process the first and foremost step would be the documentation of ethno medicinal uses of plants. Simultaneously this indigenous knowledge could be translated into commercial products on industrial scale with benefit sharing with all stake holders. Such a strategy would ensure that our bio resources are not pirated (Wagay, 2014).

Fig. 2: Categories of ethnomedicinal plants documented in Baramulla district, Kashmir.

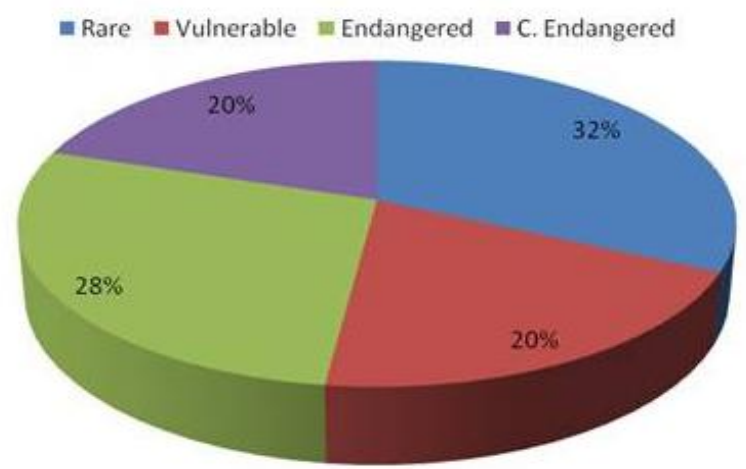


Table 1. The ethnobotanicals documented in District Baramulla, Kashmir, Jammu and Kashmir, India.

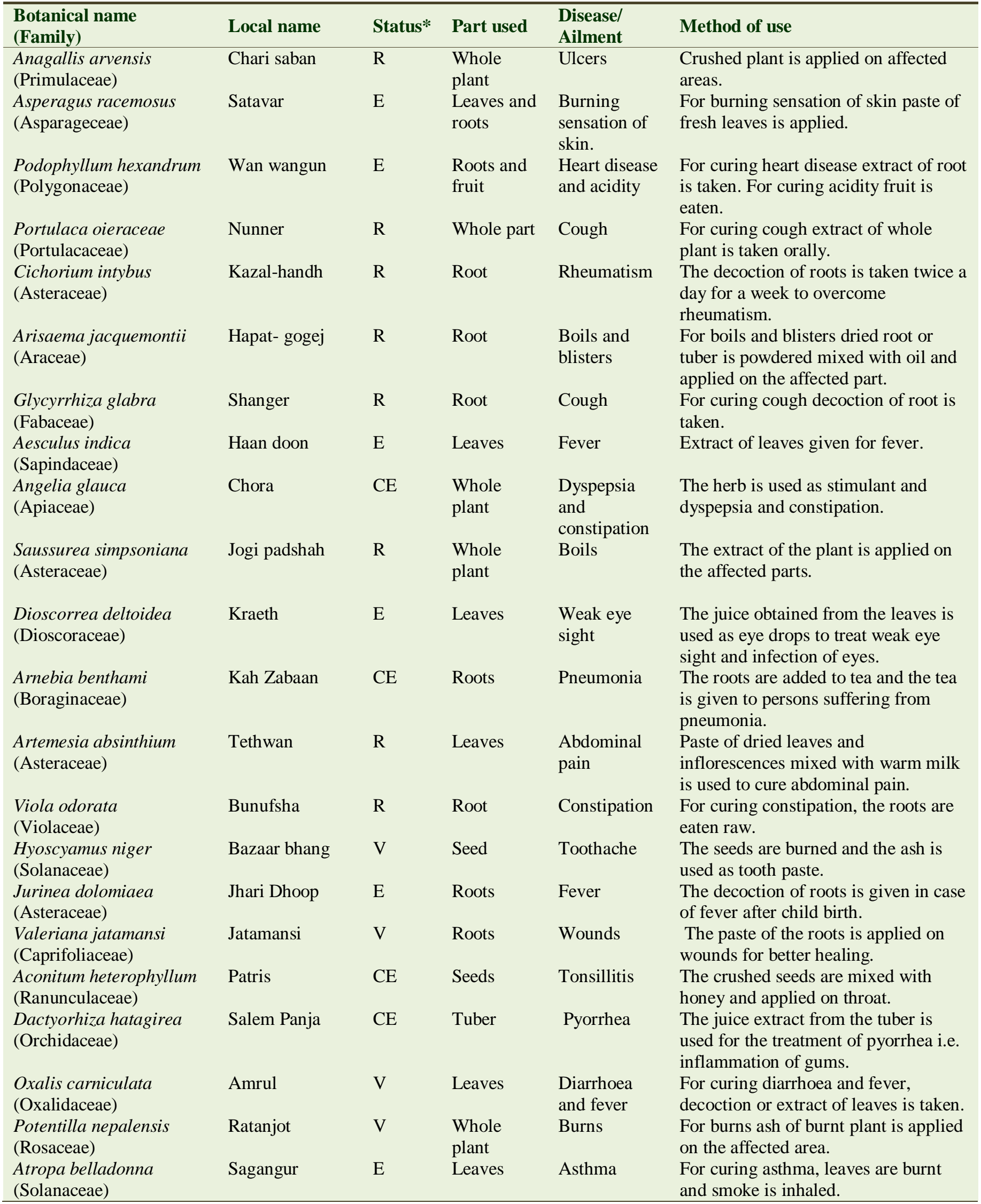




\begin{tabular}{|c|c|c|c|c|c|}
\hline $\begin{array}{l}\text { Botanical name } \\
\text { (Family) }\end{array}$ & Local name & Status* & Part used & $\begin{array}{l}\text { Disease/ } \\
\text { Ailment }\end{array}$ & Method of use \\
\hline $\begin{array}{l}\text { Bergenia ligulata } \\
\text { (Saxifragaceae) }\end{array}$ & Pashanabheda & $\mathrm{V}$ & Leaves & Wounds & $\begin{array}{l}\text { For curing wounds, paste of fresh } \\
\text { leaves is applied on the affected areas. }\end{array}$ \\
\hline $\begin{array}{l}\text { Picrorhiza kurroa } \\
\text { (Schrophulariaceae) }\end{array}$ & Coad & $\mathrm{E}$ & Rhizome & $\begin{array}{l}\text { Liver and } \\
\text { respiratory } \\
\text { disorders }\end{array}$ & $\begin{array}{l}\text { Tea is prepared from the rhizome and } \\
\text { the tea is very effective against liver } \\
\text { and respiratory disorders. }\end{array}$ \\
\hline $\begin{array}{l}\text { Euphorbia helioscopia } \\
\text { (Euphorbiaceae) }\end{array}$ & Gur-sochal & V & $\begin{array}{l}\text { Whole } \\
\text { plant }\end{array}$ & Boils & $\begin{array}{l}\text { For curing boils milk sap of whole } \\
\text { plant is applied on affected parts. }\end{array}$ \\
\hline $\begin{array}{l}\text { Colchicicum leutem } \\
\text { (Colchicaceae) }\end{array}$ & Fafoode & V & Bulb & Wounds & $\begin{array}{l}\text { The paste is applied on the wounds for } \\
\text { better healing. }\end{array}$ \\
\hline $\begin{array}{l}\text { Saussurea lappa } \\
\text { (Asteraceae) }\end{array}$ & Kouth & $\mathrm{CE}$ & Roots & $\begin{array}{l}\text { Inflammation } \\
\text { and arthritis }\end{array}$ & $\begin{array}{l}\text { The oil extracted from the root is used } \\
\text { for anti- inflammatory and pain } \\
\text { relieving purposes. The root extract } \\
\text { mixed with mustard oil is applied } \\
\text { daily for a month. }\end{array}$ \\
\hline
\end{tabular}

\section{Conclusions}

Keeping in view the high cost and side effects of allopathic medicines, the use of the medicinal plants against different ailments plays a significant role in meeting the primary health care of the rural communities of Baramulla district of Kashmir Valley. District Baramulla is fairly rich not only in medicinal plants but has also deeply rooted traditional knowledge of these medicinal plants among the people. An immensely valuable database could be the outcome of this knowledge which in turn can provide baseline information for the commercial exploitation of bioresources. This information could also be useful for the industry, pharmacologists, physicians, phytochemistry, botanists and alike interested in the development of the alternative therapies. But the traditional knowledge is draining off due to the urbanization. Also a vast number of plant species are under several threats of extinction. The major threats are overgrazing, deforestation, overexploitation, floods, soil erosion, tourism influx etc. Due to these threats, many plants have become vulnerable, endangered or critically endangered. Also Baramulla is the habitat of many rare plants. Thus the need of the hour is to speedily document this valuable information of ethno botany and also to take serious and immediate steps for the conservation of these valuable plants.

\section{Conflict of interest statement}

Authors declare that they have no conflict of interest.

\section{Acknowledgement}

We are highly thankful to the local tribal people of Baramulla District, J \& K, for their help in our data collection regarding the medicinal plants. We are also highly grateful to Botanical Survey of India (BSI), Dehradun, for indentifying some of our plant specimens.

\section{References}

Adachukwu, I.P., Yusuf, O.N., 2014. A review of ethno therapeutics of medicinal plants used in traditional/ alternative medicinal practice in eastern Nigeria. Int. J. Curr. Microbiol. Appl. Sci. 3(1), 675-683.

Agarwal, S., Kumar, V.R., Kumar, A., 2013. Ethno botanical studies on Ocimum species in Rajasthan, India. Int. Res. J. Pharm. 4(4), 228-231.

Ahmad, M., Sultana, S., Fazl-i-Hadi, S., Hadda, T.B., Rashid, S., Zafar, M., Zada Khan, M.P., Yaseen, G., 2014. An ethnobotanical study of medicinal plants in high mountainous region of Chail valley district SwatPakistan. J. Ethnobot. Ethnomed. 10, 36.

Akshay, K.R, Sudharani, N., Anjali, K.B., Deepak, T.M., 2014. Biodiversity and strategies for conservation of rare, endangered and threatened medicinal plants. Res. Rev. J. Pharmacog. Phytochem. 2(3), 12-20.

Arti, S., Kumar, S.V., Pooja, S., Sanjeeta, C., 2014. Studies on traditional knowledge on ethnomedicinal plants in Jawalamukhi, HP, India. Int. Res. J. Biol. Sci. 3(10), 6-12.

Aslam, S., Ganaie, K.A., John, A.K., Dar, G.H., 2010. Exotic ornamental flora of Kashmir Valley- An overview. New York Sci. J. 3(5), 78-82.

Bhat, T.A., Nigam, G., Majaz, M., 2012. Study of some medicinal plants of the Shopian district, Kashmir (India) with emphasis on the traditional use by Gujjar and Bakarwal tribes. Asian J. Pharmaceut. Clin. Res. 5(2), 94-98.

Das, H.B., Majumdar, K., Datta, B.K., Ray, D., 2008. Ethno botanical uses of some plants by Tripura and Reang tribe of Tripura. Ind. J. Natural Prod. Resour. 8(2), 172-180.

Dutt, A.K., Sabin, Y.K., Kapoor, L.D., 1963. Vegetation of Srinagar (Kashmir valley) with special reference to ecological habitat. Ecological Research Laboratory, Jammu-Tawi. 
Dutt, H.C., Bhagat, N., Pandita, S., 2015. Oral traditional knowledge on medicinal plants in jeopardy among Gaddi shepherds in hills of North-western Himalayas, J \& K, India. J. Ethnopharmacol. 168, 337-348.

Farooq, A. G., Saggoo, M.I.S., Dar, M.A., 2014. Ethno botany of some selected Monochlamydeae plant species from the Kashmir Himalayas, India. J. Med. Plant Res. 8(23), 834839.

Idu, Mc-D., 2009. Current trends in ethnobotany. Trop. J. Pharmaceut. Res. 8(4), 295-296.

Itoo, A., Shrivastava, P.N., Sexana, R.C., Baba, I., 2011. Ethno botanical study of plants used by the tribes of Dachigam National Park area of Kashmir valley for gastro-intestinal activity. Int. J. Indigen. Med. Plants. 29(1), 1132-1137.

Jeelani, S.M., Wani, M.P., Kumari, S., Gupta, R., Siddique, M.A.A., 2013. Ethnobotany of some polypetalous plants from the Kashmir Himalaya. J. Med. Plant Res. 7(36), 2714-2721.

Khan. Z.S., Dar, G. H., Khuroo, A.A., 2004. Ethno medical survey of Uri, Kashmir Himalayas. Ind. J. Trad. Knowl. 3(4), 351-357.

Khuroo, A.A., Malik, A.H., Dar, A.R., Dar, G.H., Khan, Z.S., 2007. Ethno veterinary medicinal uses of some plant species by the Gujjar tribe of Kashmir Himalayas. Asian J. Plant Sci. 6(1), 148-152.

Kumar, N., Wani, Z.A., Dhyani, S., 2015. Ethnobotanical study of the plants used by the local people of Gulmarg and its allied areas. Int. J. Curr. Res. Biosci. Plant Biol. 2(9), 16-23.

Lone, P.A., Bhardwaj, A. K., Bahar, F. A., 2013. A study of some locally available herbal medicines for the treatment of various ailments in Bandipora. Int. J. Pharm. Biosci. $4(2), 440-453$.
Lone, P.A., Bhardwaj, A.K., Shah, K.W., Tabasum, S., 2014. Ethno botanical survey of some threatened medicinal plants of Kashmir Himalaya, India. J. Med. Plant Res. 8 (57), 1362-1373.

Mahbubur Rehman, A.H.M., 2013. An ethnobotanical investigation on Asteraceae family at Rajshahi, Bangladesh. J. Business Admin. Manag. Sci. Res. 2(5), 133-141.

Mahesh Kumar, Yashpaul and V. K. Anand, (2009). Ethno botanical study of Indian perspective: indigenous knowledge of medicinal plants used by local in Kishtwar, Jammu and Kashmir, India. Ethnobot. Leafl. 13, 12401256.

Malik, A.H., Dar GH and Khan ZS, Khuroo, A.A., 2010. Ethno medicinal uses of some plants in the Kashmir Himalaya. Ind. J. Trad. Knowl. 10(2), 362-366.

Rout, J., Sajem, A., Nath, M., 2010. Traditional medicinal knowledge of the Zimi (Naga) tribe of north Cachar hills district Assam on the treatment of diarrhea. Assam Univ. J. Sci. Technol. Biol. Environ. Sci. 5(1), 63-69.

Shaheen, H., Nazir, J., Firdous, S. S., Khalid, A.-U.-R., 2014. Cosmetic ethnobotany practiced by tribal women of Kashmir Himalayas. Avicenna J. Phytomed. 4(4), 239250.

Sharma, A.B., 2010. Global medicinal plants demand may touch $\$ 5$ trillion by 2050 , Indian Express.

Wagay, N.A., 2014. Medicinal flora and ethno botanical knowledge of Baramulla Tehsil in Jammu and Kashmir, India. Int. J. Adv. Biotech. Res. 5(3), 539-546.

* The references cited in the text with '*' mark, have been taken from indirect sources.

\section{How to cite this article:}

Wani, Z. A., Kumar, N., Akash., 2016. Ethnobotanical study of some threatened plants in District Baramulla, Kashmir, Jammu and Kashmir, India. Int. J. Curr. Res. Biosci. Plant Biol. 3(2), 58-64. doi: http://dx.doi.org/10.20546/ijcrbp.2016.302.007 